\title{
Do changes in divorce legislation have an impact on divorce rates? The case of unilateral divorce in Mexico
}

\author{
Edith Aguirre* (1)
}

*Correspondence: sear500@york.ac.uk University of York, York YO10 5DD, UK

\begin{abstract}
In 2008, Mexico City was the first entity to approve unilateral divorce in Mexico. Since then, 17 states out of 31 have also moved to eliminate fault-based divorce. In this paper, I investigate the effect of the changes in unilateral legislation on divorce rates in Mexico, given the remarkable growth of divorce rates over the past few decades in the country, but especially after the introduction of unilateral divorce. Following a difference-in-differences methodology, two models are developed using panel state-level data. The results indicate that divorce on no grounds accounts for a $26.4 \%$ increase in the total number of divorces in the adopting states during the period 2009-2015. Moreover, since no-fault divorce has been implemented gradually in the country, the rising trend in divorce rates is expected to continue over the coming years. Unilateral legislation has proved to be an effective tool in modifying family structures in Mexico, so it is important to be aware of the short- and medium-term consequences of the shift toward divorce on no grounds, in order to improve the delivery of these policies in the country. This is especially important at this point in time, when 14 remaining states may potentially adopt unilateral legislation. This paper is the first one to address the effect of adopting unilateral divorce in the context of a Latin American country.
\end{abstract}

Keywords: Divorce rates, Unilateral divorce, Difference-in-differences, Mexico

JEL Classification: C29, J12, J18

\section{Introduction}

Divorce has legally existed in Mexico for over a century. In contrast to other countries such as Italy, Brazil, Spain, Argentina, Ireland or Chile, where divorce was forbidden until 1971, 1977, 1981, 1987, 1997 and 2004, respectively, the Mexican legislation has allowed for divorce since 1914. However, to file for divorce, a mutual agreement between the spouses had to exist; otherwise, a contested divorce (where the parties do not agree and need to fight it out in court) still had to take place. Therefore, compared to Australia or the USA, where unilateral divorce (a divorce in which one spouse ends the marriage without the consent of the other spouse) has been popular since the early 1970s, the country has lagged behind.

Divorce rates in Mexico have exhibited an upward trend in the past decades, but after the introduction of unilateral divorce in some entities, this trend has grown remarkably. Therefore, the objective of this study is to analyze whether divorce rates respond to the

(c) The Author(s) 2019. This article is distributed under the terms of the Creative Commons Attribution 4.0 International License (http://creativecommons.org/licenses/by/4.0/), which permits unrestricted use, distribution, and reproduction in any medium, provided you give appropriate credit to the original author(s) and the source, provide a link to the Creative Commons license, and indicate if changes were made. 
implementation of unilateral divorce within the context of a developing country, in this case, Mexico.

Mexico comprises 32 entities, 31 states and Mexico City. Each one of them regulates its citizens independently through their own constitutions, civil codes and penal codes, among others, which are the counterparts to the comprehensive federal regulatory structure. All petitions for divorce are handled by entity courts. In October 2008, Mexico City was the first entity to approve unilateral divorce, and since then, 17 states have also moved to eliminate fault-based divorce. It took 7 years, between 2008 and 2015, for these changes to happen in 12 entities, but in only 1 year, 2016, six more allowed no-fault divorce. ${ }^{1}$ A possible explanation for the increasing number of states that have recently modified their legislations in terms of divorce is that in July 2015, the Supreme Court of Justice of the Nation determined that it is unconstitutional for states not to allow a spouse to end a marriage unilaterally, without the need to provide a cause to dissolve the marriage. ${ }^{2}$ However, the Supreme Court resolution regarding unilateral divorce does not make any state law invalid, since it is only a jurisprudential thesis. ${ }^{3}$ From a legal perspective, unilateral divorce is therefore settled in the country, but there is an implementation problem that causes longer and strenuous divorce processes in those states that have not yet adopted divorce on no grounds. Table 1 shows the entities that have modified their local laws to adopt no-fault divorce, the year when the reform was introduced, and information about the legislation that validates unilateral divorce in the state. ${ }^{4}$

The economic literature suggests that state interventions to correct externalities are not necessary when property laws are clear and transaction costs are low because the parties will get together and negotiate a private agreement until they reach an efficient solution. Based on this assumption, efficient bargaining has been extended to marriage decisions, and the claim is that if the spouse who wishes to leave the marriage can bargain at a low cost with the spouse who wishes to stay, the only factor that matters for the dissolution of the union is the compensation negotiated, regardless of the allocation of property rights or legal liability (Becker et al. 1977). The argument is further elaborated in Becker (1991, p. 331): "A husband and wife would both consent to a divorce if, and only if, they both expected to be better off divorced. Although divorce might seem more difficult when mutual consent is required than when either alone can divorce at will, the frequency and incidence of divorce should be similar with these and other rules if couples contemplating divorce can easily bargain with each other. This assertion is a special case of the Coase theorem (1960) and is a natural extension of the argument (...) that persons marry each other if, and only if, they both expect to be better off compared to their best alternatives." The theoretical justification provided by Becker (1991) framed in terms of Coase's (1960) theorem leads to the conclusion that only inefficient marriages would disolve and efficient divorces would occur, regardless of the legal system. Therefore, modifications in divorce legislation should have no effect on the total

\footnotetext{
${ }^{1}$ No-fault divorce is a petition by either party of the marriage that does not require the petitioner to provide evidence that the defendant has breached the marital contract. However, the terms "unilateral divorce" and "no-fault divorce" are used synonymously throughout this paper because in the case of Mexico, one implies the other.

2 The declaration of unconstitutionality means that when a married individual goes to a federal judge and asks for an injunction against the state that denies the unilateral divorce, the judge must grant it.

${ }^{3}$ Jurisprudential thesis means that this determination does not directly repeal any law prohibiting unilateral divorce.

${ }^{4}$ For simplification purposes, Mexico City will be referred to as a state in the rest of the document.
} 
Table 1 Mexican states with no-fault divorce legislations

\begin{tabular}{llll}
\hline State & Year of the reform & Legislation & Article \\
\hline 1. Aguascalientes & 2015 & Civil Code & No. 288 \\
2. Baja California Sur & 2016 & Civil Code & No. 273 \\
3. Coahuila & 2013 & Family Code & No. 153 \\
4. Colima & 2016 & Civil Code & No. 268 \\
5. Guerrero & 2012 & Divorce Law & No. 27 \\
6. Hidalgo & 2011 & Family Code & No. 470 \\
7. Mexico & 2012 & Civil Code & No. 4.89 \\
8. Mexico City & 2008 & Civil Code & No. 266 \\
9. Michoacan & 2015 & Family Code & No. 254 and No. 255 \\
10. Morelos & 2016 & Family Code & No. 174 \\
11. Nayarit & 2015 & Civil Code & No. 260 \\
12. Nuevo Leon & 2016 & Civil Code & No. 267 \\
13. Puebla & 2016 & Civil Code & No. 442 \\
14. Quintana Roo & 2013 & Code of Civil Procedure & No. 985 Bis \\
15. Sinaloa & 2013 & Family Code & No. 181 \\
16. Tamaulipas & 2015 & Civil Code & No. 248 \\
17. Tlaxcala & 2016 & Civil Code & No. 106 and No. 123 \\
18. Yucatan & 2012 & Family Code & No. 191 \\
\hline
\end{tabular}

Source: Author's elaboration based on the standing legislation in each state

Legislation of the remaining 14 states not included in this table was also verified (Baja California, Campeche, Chiapas, Chihuahua, Durango, Guanajuato, Jalisco, Oaxaca, Queretaro, San Luis Potosi, Sonora, Tabasco, Veracruz and Zacatecas). Unilateral divorce is not valid in any of them

Last updated: January 2017

number of divorces, and the adoption of a no-fault divorce regime should have no effect on divorce rates.

However, critics of Becker's proposition have emerged. Even if there were perfect information and no transactional costs, it has been argued that divorce laws would affect divorce decisions because of the importance of assets and resource allocation before and after the divorce, along with divorce legislation, for determining the gains and losses from dissolution and for influencing the decision to end the marriage (Clark 1999). In addition, if Coase's theorem as applied to marriage contracts were discarded, it has been claimed that to assume that divorce rates are not influenced by divorce legislation because the gains from marriage are not affected by more liberal divorce laws would be to deny that the easier it is to get a divorce, the lower is the value of marital surplus due to more attractive outside options (Mechoulan 2005).

In an effort to reconsider the theoretical validity of the so-called Becker-Coase theorem, within the context of households that consume public as well as private goods, it has been found that as a general rule, reforms in divorce legislation are expected to affect divorce rates, but the effect can be either positive or negative, according to the situation of each couple. Moreover, this opens up the possibility that the Becker-Coase theorem can still hold, as long as the consumption of the public goods involved in the marriage is not altered after the divorce (Chiappori et al. 2015).

Sometimes changes in public policies have unintended effects on people's lives and their relationships with others. Even though no-fault divorce legislation was originally intended as a solution for inherent disputes in a fault-based divorce regime, research 
in different countries has demonstrated that unilateral divorce laws have caused an increase in the total number of divorces than would have occurred otherwise.

The discussion regarding the impact of unilateral divorce has turned into a battleground in the public sphere. While some claim that it is a less adversarial divorce system, which respects the privacy of the marriage since no evidence against either of the spouses is needed, others argue that unilateral divorce laws undermine the institution of marriage, encouraging marital irresponsibility and taking away bargaining leverage from the party who is neither at fault nor desirous of a breach, since the processes of determining property distribution, alimony and child custody are separated from the divorce trial.

To add to the debate on the effects of unilateral divorce, it has been argued that social changes after the Second World War led to a rise in the number of inefficient marriages and that no-fault legislation contributed to transforming previously inefficient marriages into efficient divorces but also to converting efficient marriages into inefficient divorces (Allen 1998). Furthermore, it has been suggested that during the period from 1965 to 1996, the adoption of unilateral divorce law in the USA caused an increase in violent crime rates of approximately $9 \%$. In the years following the reform, it was observed that mothers in adopting states were more likely to become the head of the household and to fall below the poverty line, especially less educated mothers. A potential link between the unilateral reform and the increase in crime might have been worsening in the economic conditions of mothers and the increase in income inequality as unintended consequences of the reform (Caceres-Delpiano and Giolito 2012). Empirical evidence also shows that adults who were exposed to unilateral divorces as children have lower family incomes, are less educated and separate more often (Gruber 2004). On the other hand, making divorce easier decreases domestic violence for both men and women, reduces female suicide, lowers the number of females murdered by intimates and has a positive effect on marriage investments such as female labor force participation (Stevenson and Wolfers 2006; Stevenson 2007).

Research on no-fault divorce indicates both positive and negative effects when legislation is modified to allow for unilateral divorce, depending on the particular subject under analysis. From a policy perspective, changes in divorce legislation might play an even more important role in Mexico than in developed countries, strengthening women's bargaining position in the household, where women often lack the authority to make key decisions. For instance, in terms of gender violence, data for Mexico show that around 45\% of women who have been in a relationship between 2006 and 2016 have experienced intimate partner violence. ${ }^{5}$ Unilateral divorce not only represents an option for abused wives to escape their marriages, but it also contributes to reducing domestic violence because husbands are less likely to abuse given a more credible threat to leave the marriage. Women in developing countries are also more economically dependent. Mexican female labor market participation is below the average for OECD countries with the second lowest rate only after Turkey (OECD 2017). As a result, the potential costs of divorce that Mexican married women bear can be disproportionately higher relative to men. Divorce on no grounds reduces the time spent on accusations and legal

${ }^{5}$ National Surveys on the Dynamics of Household Relationships (ENDIREH), 2006, 2011 and 2016. 
fees, helping women cope better with the financial divorce burdens and increasing their chances to end a bad marriage.

In this paper, to analyze the unilateral divorce effect on divorce rates in Mexico, a difference-in-differences (DD) analysis is conducted using aggregate divorce data at the state level following the methodology proposed by Wolfers (2006) and Friedberg (1998). In each year, the states that have adopted unilateral divorce are considered the treatment group, while the states that remain under the fault-based legislation are considered the control group. The DD technique has been used widely to study numerous policy questions, and it is considered a popular tool for applied research in economics.

The results indicate that the shift toward divorce on no grounds raises the divorce rate by 0.30 annual divorces per thousand people and accounts for a $26.4 \%$ increase in the total number of divorces in the states that modified their legislation during the period 2009-2015. To the best of my knowledge, this is the first study to analyze the impact of unilateral legislation on divorce rates in a Latin American country, and it aims to contribute to a better understanding of divorce outcomes in the region, as well as the implications of these types of polices in developing countries.

The remainder of the paper is outlined as follows: Section 2 introduces the relevant literature; Sect. 3 discusses the estimation strategy; Sect. 4 presents the data; Sect. 5 shows the results for the static and dynamic specifications, as well as the results for alternative empirical approaches that are followed; and Sect. 6 presents the conclusions.

\section{Literature review}

Over the last 30 years, economists have devoted considerable empirical efforts to find out whether liberalization in divorce laws is responsible for the rise in marital dissolution. Initially, unilateral legislation was found not to have an effect on the probability that a woman becomes divorced in the USA (Peters 1986), supporting the validity of the Becker-Coase theorem. However, in an open criticism of this work, it was argued that the findings are wrong, mainly due to the misclassification of no-fault and fault states and the inclusion of regional dummies and that once the methodological issues are corrected, the results show that the shift from fault to no-fault divorce regime indeed increases divorce rates (Allen 1992).

As an alternative to deal with the lack of robustness of previous research, using a panel of state-level divorce rates for the USA, a difference-in-differences methodology is followed to identify the effect of unilateral divorce on divorce rates (Friedberg 1998). The main concern to address is endogeneity, given the earlier adoption of unilateral legislation in states with higher divorce rates. Estimations are performed using the number of divorces that occur within a state each year as the dependent variable divided by the state population in thousands. For the main independent variable, a dichotomous variable is created, which takes the value of 1 if the state had adopted unilateral legislation in that year and zero otherwise. State effects, year effects and state-specific linear and quadratic time trends are included as controls. The findings show not only that states with legislation toward unilateral divorce have higher divorces rates but that during the period from 1968 to 1988, unilateral divorce also accounted for 17\% of the rise in divorce rates, suggesting a more permanent rather than temporal effect. 
In order to reassess whether the short-run and long-run implications of the shifts in divorce regimes are different, previous research was expanded to incorporate the dynamics of divorce responses (Wolfers 2006). The argument for the extension of the analysis is based on the notion that state-specific trends might be capturing not only preexisting trends but also the dynamic effects of the change in the legislation, confounding the two of them. To address this possibility, similar regressions to Friedberg's are estimated, but the sample period is modified to 1956-1988 and eight dichotomous variables are created to indicate whether the adoption of unilateral legislation had been in place for at least 2 years, 3-4 years, 5-6 years, 7-8 years, 9-10 years, 11-12 years, 13-14 years or 15 years or more. The results indicate that a change in divorce legislation leads to a temporary increase in divorce rates but that there is no evidence to suggest that this rise is permanent, showing that after a decade, the rise is reversed.

Similar research has been carried out to analyze the effect of changes in divorce legislation on divorce rates in Europe. Pooling data together from 18 countries (Austria, Belgium, Denmark, Finland, France, Germany, Greece, Iceland, Ireland, Italy, Luxembourg, Netherlands, Norway, Portugal, Spain, Sweden, Switzerland and the United Kingdom), the evidence supports previous findings that modifications in divorce law increase divorce rates, with strong long-term effects (Gonzalez and Viitanen 2009).

Furthermore, following an interactive fixed-effects approach, for a given number of factors (Kim and Oka 2014), and for an unknown number of factors (Moon and Weidner 2015), a short-term effect on divorce rates due to unilateral legislation in the USA has also been found. The purpose of using an interactive fixed-effects model in this context is to control for unobserved heterogeneity across states (family size, religious beliefs and female labor force participation) that might evolve over time in a complex way, leading to mixed empirical evidence. Wolfers' specifications are followed, but the random error is assumed to consist of unobserved common shocks and an idiosyncratic error. Estimations are performed following Bai (2009) and the least squares (LS) estimator, respectively. It is important to highlight that the interactive fixed-effects methodologies used within this context are only valid for panel data with large cross-sectional units $(N)$ and large time periods (T). ${ }^{6}$ Their potential implementation therefore relies on the specific characteristics of the datasets available. In this case, the panel data consist of 48 states over 33 years. ${ }^{7}$

For developing countries, and more precisely for Latin American countries, scholarly economic research on the effects of unilateral legislation on divorce rates is scarce. This is not surprising, as no-fault divorce has been in place only for a few years in some of these countries, and there is limited quantitative information available to analyze its consequences for the structure of families. It is expected that this paper will stimulate interest in monitoring, reporting and evaluating the effects of these changes in the policies in the region and that more research will take place to better understand the role that they play, given their specific cultural context.

\footnotetext{
${ }^{6}$ Usually, both $N$ and $T$ are larger than 30.

7 This is different from Friedberg and Wolfers, given the need for a balanced panel in interactive fixed effects.
} 


\section{Estimation strategy}

To analyze whether divorce rates in Mexico are responding to the implementation of nofault divorce, initially, the difference-in-differences estimation approach used by Friedberg (1998) is followed:

$$
\begin{aligned}
\text { Divorce Rate }_{s, t}= & \beta \text { Unilateral }_{s, t}+\sum_{s} \text { State fixed effects }_{s} \\
& +\sum_{y} \text { Year fixed effects }_{y}+\sum_{s} \text { State }_{s} * \text { Time }_{t} \\
& +\sum_{s} \text { State }_{s} * \text { Time }_{t}^{2}+\varepsilon_{s, t}
\end{aligned}
$$

where Divorce Rate is the total of divorces per thousand people ${ }^{8}$ and Unilateral is a binary indicator for divorce legislation (unilateral $=1$ ). State-fixed effects are included to control for heterogeneity within states. Year-fixed effects account for changes in divorce patterns at a national level. Linear and quadratic state-specific time trends capture changes within states $(s)$ over time $(t)$.

In contrast to other papers where an important issue is the classification of state divorce laws, which has the potential to reach different conclusions depending on the definition used, in the Mexican case this is not a problem. Although no-fault divorce and unilateral divorce correspond to different situations, according to the reforms adopted in Mexico, each state that has eliminated grounds for divorce has simultaneously incorporated unilateral divorce in its legislation.

As mentioned in the previous section, Friedberg's methodology poses the latent risk of confounding preexisting trends with the full adjustment of divorce rates after the change in legislation. To rule out this possibility, Eq. (1) is modified to capture the dynamic response of the policy reform and Eq. (2) is also estimated. It is worth emphasizing that this should not be seen as a mere extension or a robustness check but as a better specification to control for the dynamics generated in the marriage market. The results obtained will help determine if the introduction of unilateral divorce has had a more temporal rather than a permanent effect on divorce rates.

$$
\begin{aligned}
\text { Divorce Rate }_{s, t}= & \sum_{k \geq 1} \beta_{k} \text { Unilateral divorce has been in effect for } k \text { periods }_{s, t} \\
& +\sum_{s} \text { State fixed effects }_{s}+\sum_{y} \text { Year fixed effects } \\
& +\sum_{s} \text { State }_{s} * \text { Time }_{t}+\sum_{s} \text { State }_{s} * \text { Time }_{t}^{2}+\varepsilon_{s, t}
\end{aligned}
$$

The binary indicator for divorce legislation in Eq. (1) is substituted by three dummy variables that indicate if unilateral divorce has been effective for 1 to 2 years, 3 to 4 years and

\footnotetext{
${ }^{8}$ It has been argued that the divorce rate should be measured using the number of marriages instead of the population. However, since the information on marriages is not readily available, this definition of the divorce rate has been commonly accepted.
} 
5 years or more. The inclusion of these variables allows us to identify to what extent the increase in divorce rates is affected by modifications in divorce legislation (Wolfers 2006).

Heterogeneity across states and time exists and may affect divorce rates and divorce legislation. The inclusion of factors such as unemployment and fertility rates in the standard approach allows for estimating the parameters more precisely (Gonzalez and Viitanen 2009). Equations (1) and (2) are thus re-estimated including the following set of controls: female labor force participation, unemployment, fertility rate, education and gross domestic product.

Since the divorce rate is the total of divorces per 1000 population, the error term represents the sum of all individual disturbances in a state $(s)$ at time $(t)$, divided by the population, leading to heteroscedasticity. In order to correct standard errors and to gain efficiency, weighted least squares (WLS) using population is implemented to perform all estimations. ${ }^{9}$

\section{Data}

The National Institute of Statistics and Geography (INEGI) provides information on all the divorce records registered in the country by year. For the purposes of this analysis, state-level panel data are used for a period of 10 years, from 2005 to 2015. Although Mexico City was the first entity to adopt unilateral divorce in 2008, and since then 17 more states have changed their divorce legislation to divorce on no grounds, the sample is also extended back to 2001 and 1993, in order to address potential preexisting statespecific trends, and to verify whether the main results are still valid.

Table 5 in Appendix shows the divorce rates by state for the period analyzed. For most of the states that have shifted to unilateral legislation, a substantial rise in the divorce rates is observed in the year when no-fault divorce is adopted or in the year after, and no anticipation effect is identified prior to the change in law. Thus, for those states that modified their legislation in the second half of the year, the first year considered as affected by the reform is the next year. ${ }^{10}$ Following this approach, and since divorce data are available up to 2015, there are ten treatment states included in the analysis: Aguascalientes, Coahuila, Mexico City, Guerrero, Hidalgo, Mexico, Nayarit, Quintana Roo, Sinaloa and Yucatan. ${ }^{11}$ Table 5 does not indicate any systematic increase in divorce rates before the adoption of unilateral divorce, suggesting no endogenous legislation. It was verified whether a correlation exists between the initial divorce rates and the change in a state's divorce law and between the initial divorce rates and the year when the state adopted divorce on no grounds. The lack of significance of all the correlation coefficients reported in Table 6 in Appendix suggests that it is unlikely that a reverse causality exists and that the shift toward no-fault divorce is exogenous rather than caused by a preexisting rise in divorce rates in the adopting states.

\footnotetext{
${ }^{9}$ Following Hsiao (2014), when using standard errors clustered by the cross-sectional variable, the number of groups should be large. This supports the use of WLS as a more appropriate strategy, given that there are only 32 states in the analysis.

10 Baja California Sur, Mexico City, Michoacan, Nuevo Leon, and Tamaulipas are in this situation.

11 As Table 1 indicates, during the period from 2008 to 2016, 18 states changed their divorce law. However, divorce data are not yet available for 2016, so the six states that moved toward unilateral divorce in 2016 (Baja California Sur, Colima, Morelos, Nuevo Leon, Puebla and Tlaxcala) and the two states that shifted to it in the second half of 2015 (Michoacan and Tamaulipas) are not included as treatment states in the analysis.
} 
It is also relevant to ask to what extent the inclusion of state-level fixed effects in the model is justified in order to control for different unobserved state-level factors affecting divorce rate trends. Figure 1 in Appendix illustrates the average divorce rate for the group of states that have adopted no-fault divorce (treatment states) and those who remain under the traditional divorce legislation (control states) for the period 19932015. The difference observed between the average divorce rates for the treatment and control groups is close to zero during the first 10 years, but it starts to gradually increase afterward, providing evidence for differentiated trends and reaching a maximum of 0.32 in 2015. Similar average divorce rates, especially before any state adopted no-fault divorce, could be an early indication that unobserved heterogeneity across states does not present a threat of omitted variable bias, suggesting that state-level fixed effects might not play as much of a crucial role in Mexico as in other countries.

Data on the state population are needed to obtain the divorce rates. The National Population Council (CONAPO) only provides projected estimates for the period 2010 to 2015; therefore, the Mexican Labor Force Survey (ENOE) collected by INEGI is a more accurate source of these data, as well as for female labor force participation and unemployment rates. Fertility rates and gross domestic product were also obtained from INEGI, and education data were obtained from the Secretariat of Public Education (SEP). Finally, the standing legislation in each state has been verified to fully identify the states that have legalized unilateral divorce versus those that are still requiring grounds to grant divorce.

In contrast to the dataset used for the USA, a potential limitation in the Mexican case is the borderline small number of cross-sectional units (32 states) and time periods (10 years) available to conduct the analysis. It has been customary in difference-indifferences empirical applications to overlook the possible consequences of the terms of statistical inference within this context, but a growing body of the literature acknowledges the need for alternative techniques to properly account for problems such as serially correlated errors, cross-sectional dependence and heteroscedasticity (Donald and Lang 2007; Conley and Taber 2011; Ferman and Pinto 2018). There is no consensus on a straightforward approach to follow, and each method that has been established, such as cluster residual bootstrap, synthetic control estimator, feasible generalized least squares and two-step estimators, among others, aims to deal with specific circumstances. Moreover, as indicated earlier, there are ten states in Mexico that have shifted their legislation toward unilateral divorce in the dataset available (treatment states); for two of them, however, Aguascalientes and Nayarit, the change only took place in the last year, 2015. This poses an additional challenge for identifying the true effect of the policy change, rather than its immediate effect. The development of a new inference method in the current Mexican setting is out of the scope of this paper, but the study takes a proactive approach and provides sensitivity analyses and robustness checks that aim to validate the main results obtained following the standard approach.

\section{Results}

The results are presented in the following sections. Section 5.1 shows the estimations for the static specifications, while Sect. 5.2 presents the outcomes when the model is enhanced to properly capture the dynamic response of divorce rates. In Sect. 5.3, control 
Table 2 Static effects on divorce rates-2005 to 2015

\begin{tabular}{|c|c|c|c|c|}
\hline & (1) & (2) & (3) & (4) \\
\hline Unilateral & $\begin{array}{l}0.394^{* * *} \\
(0.0532)\end{array}$ & $\begin{array}{l}0.321 * * * \\
(0.0271)\end{array}$ & $\begin{array}{l}0.300^{* * *} \\
(0.0319)\end{array}$ & $\begin{array}{l}0.231^{* * *} \\
(0.0345)\end{array}$ \\
\hline Adjusted $R^{2}$ & 0.133 & 0.896 & 0.943 & 0.955 \\
\hline Year effects & No & Yes, $F=8.85$ & Yes, $F=2.22$ & Yes, $F=1.18$ \\
\hline Prob $>F$ & & 0.000 & 0.017 & 0.304 \\
\hline State effects & No & Yes, $F=81.15$ & Yes, $F=37.75$ & Yes, $F=26.66$ \\
\hline Prob $>F$ & & 0.000 & 0.000 & 0.000 \\
\hline State trend, linear & No & No & Yes, $F=9.32$ & Yes, $F=2.64$ \\
\hline Prob $>F$ & & & 0.000 & 0.000 \\
\hline State trend, quadratic & No & No & No & Yes, $F=3.32$ \\
\hline Prob $>F$ & & & & 0.000 \\
\hline Total of observations & 352 & 352 & 352 & 352 \\
\hline
\end{tabular}

Source: National Institute of Statistics and Geography (INEGI) and standing legislation in each state. Divorce rates are measured as total of divorces per thousand people. Standard errors are in parentheses. All regressions include a constant term and are estimated using state and year population-weighted least squares

${ }^{* * *}$ Statistically significant at the $99 \%$ confidence level

variables are added to the static and dynamic models to account for observed heterogeneity, and in Sect. 5.4, alternative empirical approaches are followed to determine if the main conclusions continue to be valid.

\subsection{Static specifications}

Table 2 reports estimates of the static effects on divorce rates when unilateral legislation is adopted. The estimates suggest that unilateral divorce raises divorce rates in Mexico. All coefficients of unilateral are statistically significant. The first specification in column (1) does not include fixed effects, and it is observed that its coefficient for unilateral is the largest. It captures not only the effect of the modification in the divorce legislation but also other changes on divorce patterns over time and across states. To improve the model, controlling for the average differences in states and years, specification (2) includes year and state effects. The coefficient indicates that the adoption of unilateral divorce raises the divorce rate by 0.32 annual divorces per thousand people. While the year effects capture evolving unobserved characteristics at a country level, and the state effects control for constant factors over time that influence divorce decisions; specifications (3) and (4) represent more flexible models where attributes that affect divorce propensities in each state are allowed to change over time. The results exhibit a smaller effect of no-fault divorce when linear and quadratic state trends are included.

The $F$ statistics for the state trends in columns (3) and (4) show that the significance level of the test equals zero, reflecting that state trends are jointly significant, both linear and quadratic. In addition, moving across the columns, the adjusted $R^{2}$ increases from 0.89 in specification (2) to 0.95 in specification (4), supporting the inclusion of state trends as relevant to the model. A possible explanation for the modest variation in the unilateral coefficient when state trends are added, compared to other countries such as the USA, might be the homogenous gender inequality that is predominant in all Mexican states to this day. Women's decision-making power within the household is limited in the country, and therefore only an external shock such as an unexpected change in the 
divorce legislation triggers a structural change in the marriage market, disrupting traditional gender roles and stereotypes. It may also be the case that the main factors that have an impact on divorce rates within states have not changed much over the period analyzed. In Sect. 5.3, the results are presented when some of these potential factors are explicitly included in the estimations. As an only exception, in specification (4), the $F$ test for the year effects fails to reject the null hypothesis that the coefficients for all years are jointly equal to zero, suggesting that there is no need to include year-fixed effects in the model. Table 7 in Appendix provides the estimations for all specifications excluding year effects. The impact of unilateral legislation on divorce rates remains positive, significant and similar in magnitude.

Considering that Friedberg (1998) used specifications similar to those in Table 2 for the USA and obtained a variation between 0.004 and 1.80 in annual divorces per thousand people due to unilateral legislation, it can be argued that in the case of Mexico, regardless of the model used, the static effects of unilateral legislation do not vary much across specifications, from 0.23 to 0.39 . This suggests that the model is appropriate for the country and that there is a strong and steady relationship between changes in divorce law and divorce rates in Mexico. The unilateral coefficient in specification (3), for instance, represents $34.9 \%$ of the average divorce rate of 0.85 annual divorces per 1000 population for the period analyzed. Moreover, the adoption of unilateral legislation has increased the divorce rate by $26.4 \%$ in the shifting states during the period 2009-2015.

An issue for the robustness of the results presented above is the number of years considered in the analysis before the policy shock, to properly account for preexisting state trends. This is less of a problem for those states that have shifted to unilateral divorce more recently but remains a controversy for those that started earlier, such as Mexico City (2008) or Hidalgo (2011). Table 3 reports the static effects on divorce rates for the period 2001 to 2015. Comparing Tables 2 and 3, it is observed that the inclusion of additional years pre-reform plays no major role in the analysis. Estimations for a larger period, from 1993 to 2015, are also provided in Table 8 in Appendix, and the findings remain unchanged. It is to be noted that adding data where all states are untreated (1993 to 2004) tends to increase the unilateral coefficient. For instance, in Table 2, specification (4) indicates that no-fault legislation raises divorce rates by 0.23 annual divorces per thousand people, whereas in Table 3, specification (4) shows an increase in 0.29 annual divorces per thousand people. Contrary to what is observed, it is expected that adding data where all states are untreated would reduce the coefficient. This finding might reflect the almost null variation in divorce rates during the pre-reform years at the national level, reinforcing the effect of the change in the divorce legislation rather than diluting it when the data are extended back. According to data from INEGI, in 1990 and 2000, there were seven divorces for every 100 new marriages. By 2005, this rate rose to 11.8, and in 2015, it reached 22 per 100 new marriages (see Fig. 2 in Appendix).

\subsection{Dynamic specifications}

The aim of this section is to examine the potential bias resulting from unmeasured confounders. As mentioned earlier, outcomes from Eq. (1) might be biased measures of the causal effect of unilateral divorce on divorce rates because the unilateral coefficient is not allowed to change after the adoption of no-fault divorce, confounding preexisting trends 
Table 3 Static effects on divorce rates-2001 to 2015

\begin{tabular}{|c|c|c|c|c|}
\hline & (1) & (2) & (3) & (4) \\
\hline Unilateral & $\begin{array}{l}0.433^{* * *} \\
(0.0499)\end{array}$ & $\begin{array}{l}0.295^{* * *} \\
(0.0252)\end{array}$ & $\begin{array}{l}0.327^{* * *} \\
(0.0277)\end{array}$ & $\begin{array}{l}0.291^{* * *} \\
(0.0297)\end{array}$ \\
\hline Adjusted $R^{2}$ & 0.134 & 0.883 & 0.939 & 0.954 \\
\hline Year effects & No & Yes, $F=14.14$ & Yes, $F=1.66$ & Yes, $F=1.92$ \\
\hline Prob $>F$ & & 0.000 & 0.060 & 0.023 \\
\hline State effects & No & Yes, $F=93.12$ & $Y e s, F=40.24$ & Yes, $F=25.27$ \\
\hline Prob $>F$ & & 0.000 & 0.000 & 0.000 \\
\hline State trend, linear & No & No & $Y e s, F=13.78$ & Yes, $F=4.47$ \\
\hline Prob $>F$ & & & 0.000 & 0.000 \\
\hline State trend, quadratic & No & No & No & $Y e s, F=5.48$ \\
\hline Prob $>F$ & & & & 0.000 \\
\hline Total of observations & 480 & 480 & 480 & 480 \\
\hline
\end{tabular}

Source: National Institute of Statistics and Geography (INEGI), National Population Council (CONAPO) for states' population from 2001 to 2004, and standing legislation in each state. Divorce rates are measured as total of divorces per thousand people. Standard errors are in parentheses. All regressions include a constant term and are estimated using state and year population-weighted least squares

***Statistically significant at the $99 \%$ confidence level

with the dynamic effects of the policy shock. When a policy shock takes place, depending on the circumstances, the impact may be immediate or occur with considerable delay; it either has a permanent effect or dies out at a relatively fast pace. Wolfers (2006) analyzes the short-, medium- and long-run effects of the adoption of unilateral law in the USA. In the case of Mexico, the shift toward no-fault divorce is a recently enacted legislation, starting in 2008, so the analysis is focused on the short and medium term. Table 4 presents the effects that unilateral legislation has on divorce rates within the first 2 years of the change in the law, during years 3 and 4 and after 5 or more years. All unilateral coefficients are statistically significant, with the exception of column (4) after 5 years or more. State trends are jointly significant, and the adjusted $R^{2}$ increases from specification (1) to (4).

According to estimates in columns (2) to (4), the introduction of unilateral reforms increases divorce rates in the short run from 0.21 to 0.28 annual divorces per thousand people. Over years 3 and 4, the effect increases in size for specifications (2) and (3) and remains very similar for specification (4). Finally, 5 or more years after the reform, the impact is still positive but starts to diminish, affecting divorces rates by 0.29 and 0.25 annual divorces per 1000 people, according to specifications (2) and (3), respectively. Tests have been performed on the equality of the three coefficients of unilateral in each specification, rejecting the hypothesis that they are similar for specifications (3) and (4) at standard confidence levels, supporting the strategy followed in this section. A potential explanation of the higher effect of the change in law in years 3 and 4, rather than during the first 2 years, is that initially, the changes in the divorce regime are not widely known by the population, taking time for the information to be disseminated. Time is also necessary for divorce to become more acceptable, and people gradually become more open to ending a marriage that no longer works as more couples get separated. In addition, the process of filing for divorce under different rules can be difficult to understand at the beginning, delaying the decision. The positive but smaller size of the effect on divorce rates of no-fault divorce after 5 or more years indicates that although the dynamic response to the policy shock persists in the medium term, the effect of the law change over the following years 
Table 4 Dynamic effects on divorce rates-2005 to 2015

\begin{tabular}{|c|c|c|c|c|}
\hline & (1) & (2) & (3) & (4) \\
\hline \multicolumn{5}{|l|}{ Unilateral } \\
\hline First 2 years & $\begin{array}{l}0.336^{* * *} \\
(0.0765)\end{array}$ & $\begin{array}{l}0.285^{* * *} \\
(0.0322)\end{array}$ & $\begin{array}{l}0.276^{* * *} \\
(0.0332)\end{array}$ & $\begin{array}{l}0.216^{* * *} \\
(0.0367)\end{array}$ \\
\hline Years 3 and 4 & $\begin{array}{l}0.424^{* * *} \\
(0.0804)\end{array}$ & $\begin{array}{l}0.371^{* * *} \\
(0.0351)\end{array}$ & $\begin{array}{l}0.363^{* * *} \\
(0.0454)\end{array}$ & $\begin{array}{l}0.215^{* * *} \\
(0.0615)\end{array}$ \\
\hline 5 years or more & $\begin{array}{l}0.482^{* * *} \\
(0.126)\end{array}$ & $\begin{array}{l}0.299^{* * *} \\
(0.0559)\end{array}$ & $\begin{array}{l}0.259^{* * *} \\
(0.0839)\end{array}$ & $\begin{array}{l}0.0347 \\
(0.109)\end{array}$ \\
\hline Adjusted $R^{2}$ & 0.131 & 0.897 & 0.945 & 0.956 \\
\hline Year effects & No & Yes, $F=7.82$ & Yes, $F=1.67$ & $Y e s, F=1.37$ \\
\hline Prob $>F$ & & 0.000 & 0.086 & 0.193 \\
\hline State effects & No & Yes, $F=82.08$ & Yes, $F=38.59$ & Yes, $F=27.09$ \\
\hline Prob $>F$ & & 0.000 & 0.000 & 0.000 \\
\hline State trend, linear & No & No & Yes, $F=9.63$ & Yes, $F=2.54$ \\
\hline Prob $>F$ & & & 0.000 & 0.000 \\
\hline State trend, quadratic & No & No & No & Yes, $F=3.16$ \\
\hline Prob $>F$ & & & & 0.000 \\
\hline Equality of coefficients & $F=0.63$ & $F=2.58$ & $F=5.26$ & $F=3.10$ \\
\hline Prob $>F$ & 0.535 & 0.077 & 0.005 & 0.046 \\
\hline Total of observations & 352 & 352 & 352 & 352 \\
\hline
\end{tabular}

Source: National Institute of Statistics and Geography (INEGI) and standing legislation in each state. Divorce rates are measured as total of divorces per thousand people. Standard errors are in parentheses. All regressions include a constant term and are estimated using state and year population-weighted least squares

***Statistically significant at the $99 \%$ confidence level

might gradually be reduced as an adjustment to a temporary boom of inefficient marriages breaking up immediately after the reform. It is important to highlight that comparing the static and dynamic estimates for unilateral in Tables 2 and 4, the coefficients do not vary much and remain very similar, confirming a close relationship between changes in divorce legislation and divorce rates, regardless of the approach that is followed.

\subsection{Control variables}

To explicitly account for observed heterogeneity, five variables are included in the analysis: education, ${ }^{12}$ female labor force participation, fertility rates, ${ }^{13}$ gross domestic product (GDP) and unemployment. The inclusion of these controls aims to reassess the impact of unilateral legislation on divorce rates when some state-level variables are added to the model. The results for the static and dynamic specifications, reported in Tables 9 and 10 in Appendix, are virtually identical to those presented in Sects. 5.1 and 5.2 for the effect of divorce legislation, validating the inclusion of state-fixed effects and trends in the analysis in order to capture the effect of other factors that affect divorce rates.

In terms of the new variables added to the model, only unemployment turned out to be significant in most specifications. However, contrary to what the literature suggests (Becker et al. 1977), an increase in unemployment leads to an unexpected reduction in divorce rates in Mexico. An explanation for this is that divorce itself costs money, so the inability to afford a divorce for individuals facing unemployment, and the fact that it costs more for a couple to live separately than together, may be preventing married couples

\footnotetext{
${ }^{12}$ Average grade of schooling.

13 Total number of live births per 1000 females of childbearing age between the ages of 15 and 49 years.
} 
in developing countries from filing for divorce when unemployment rates are higher. Another possible explanation is that marriage might be seen as some sort of informal insurance against unemployment, becoming more valuable when unemployment is high.

\subsection{Unweighted specifications and changes in the functional form}

All of the previous estimations have been performed using weighted least squares (WLS) to correct for the presence of heteroscedasticity generated by the use of statelevel divorce rates rather than individual data on divorce decisions. However, it has been argued that estimations under WLS and ordinary least squares (OLS) should be similar if the unobserved heterogeneity is adequately addressed (Kim and Oka 2014). Following Droes and Lamoen (2010), the transformed model using analytical weights is:

$$
\begin{aligned}
& \text { Divorce Rate } s, t \sqrt{\operatorname{pop}_{s, t}}=\beta \text { Unilateral }_{s, t} \sqrt{\text { pop }_{s, t}} \\
& +\sum_{s} \text { State fixed effects } \sqrt{\text { pop }_{s, t}}+\sum_{y} \text { Year fixed effects } y \sqrt{\text { pop }_{s, t}} \\
& +\sum_{s} \text { State }_{s} * \text { Time }_{t} \sqrt{\operatorname{pop}_{s, t}}+\sum_{s} \text { State }_{s} * \text { Time }_{t}^{2} \sqrt{\text { pop }_{s, t}}+\varepsilon_{s, t} \sqrt{\text { pop }_{s, t}}
\end{aligned}
$$

where pop is the state population in thousands. It is observed that the coefficient for unilateral divorce remains equal after the transformation. Lee and Solon (2011), and Droes and Lamoen (2010), using Wolfers (2006) and Friedberg's (1998) data, estimate the effect of unilateral divorce using OLS. In addition, Lee and Solon (2011) perform estimations using the logarithm of the divorce rate, claiming that this is also a valid functional specification. The results for the USA suggest that the change in law has no effect on divorce rates, neither when OLS regressions are estimated nor when the dependent variable in the analysis is the divorce rate in log, casting doubt on the true effect of unilateral legislation in that country.

Weighting by population to correct for heteroscedasticity in order to obtain efficient estimators relies on the strong assumption of homoscedastic and independent error terms for individuals within the state. However, if individual error terms share a common state-level error component, the unweighted state-average error terms are closely homoscedastic. In this scenario, the use of WLS would exacerbate any existing heteroscedasticity, and OLS estimation would be more efficient than WLS. Large discrepancies between the results obtained using WLS and OLS might be an indication of functional form or model misspecification. Therefore, estimations based on OLS without weighting are also important to perform and report. Likewise, given the nature of the dependent variable used within this context, an always positive divorce rate, it is possible to consider different functional specifications, such as the logarithm of divorce rates. Typically, the results based on changes in functional form assumptions are expected not to be extremely sensitive to these modifications, supporting previous findings and providing compelling evidence for the main conclusions in the analysis.

To determine if the results obtained for Mexico are still valid following these approaches, Tables 11 and 12 in Appendix report the OLS estimates, and Tables 13, 14, 15 and 16 present the estimations when using the log of the divorce rate. As discussed by Lee and Solon (2011), the OLS coefficients obtained are smaller than the WLS estimates, given that WLS places more weight on those states that are more populated, and given that unilateral divorce has larger effects on these states. However, in contrast to 
the results for the USA, the coefficients obtained for unilateral legislation continue to be positive and statistically significant in practically all specifications. These findings provide compelling evidence that unilateral divorce has an effect on the divorce rates in Mexico, regardless of the estimation methods or the functional form assumed.

\section{Conclusion}

This study evaluates the effect of unilateral legislation on divorce rates in Mexico. A large number of economic research studies have analyzed the relationship between these two variables by using different methodologies. Findings for the USA and Europe indicate that no-fault divorce has an undeniable role in explaining the increases in divorce rates. However, there are no previous studies analyzing the consequences of unilateral legislation on divorce rates in Latin America, possibly because divorce on no grounds is a recently enacted legislation in the region.

Following a difference-in-differences approach, two models are developed using panel state-level data. The preferred static specification indicates that the shift toward divorce on no grounds raises the divorce rate by 0.30 annual divorces per thousand people and accounts for the $26.4 \%$ increase in the total number of divorces in the adopting states during the period 2009-2015. In order to distinguish between the immediate effects of the policy shock and the impact that it has in the medium run, a dynamic model is also estimated. The preferred dynamic specification suggests that during the first 2 years after the change in law, the divorce rate increases by 0.27 annual divorces per thousand people, but in the third and fourth years, the effect is even larger with 0.36 annual divorces per thousand people. Five or more years after the reform, although the effect is still positive and significant, a smaller effect of 0.25 divorces per 1000 population per year is observed. These results may be an indication of an inverted U-shaped relationship between the divorce rates and changes in divorce law over time in Mexico. In addition, they illustrate the importance of promoting information about the reform.

The positive effect of unilateral legislation on divorce rates rejects the empirical validity of the Becker-Coase theorem for Mexico, at least in the short and medium term. Moreover, since divorce on no grounds has been adopted gradually in the country by different states, the rising trend in divorce rates is expected to continue over the following years.

The findings of this research are relevant for the country, especially during this transition period, when a total of 18 states have already changed their divorce legislation toward no-fault divorce, but there are still 14 states remaining that may potentially adopt unilateral divorce. First, they explain the higher divorce rates observed in Mexico, particularly over the last few years. Moreover, they shed light on the effectiveness of these types of policies, allowing individuals who no longer wish to remain in a marriage to end it in a less costly, time-consuming and strenuous way. However, they also pose the question of whether relaxing divorce laws encourages couples to give up more easily on their marriages, especially younger people, and undermines the institution of marriage. In terms of additional policy implications typically associated with other countries that allow unilateral divorce, there is a lack of studies in Mexico and Latin America. More research on the region is needed to understand the effects of changes in divorce legislation on domestic violence, female labor force participation, fertility rates, children 
outcomes and income inequality, among others. Since unilateral legislation has proved to be an effective tool for modifying family structures in Mexico, it is important for policy makers to be aware of the consequences of the shift toward unilateral divorce in order to deliver changes in divorce laws more effectively.

\section{Supplementary information}

Supplementary information accompanies this paper at https://doi.org/10.1186/s40503-019-0071-7.

Additional file 1. Divorce law on divorce rates.

Additional file 2. Endogenous legislation.

Additional file 3. Equality of coefficients for dynamic specifications.

Additional file 4. Data set 2005.

Additional file 5. Data set 2001.

Additional file 6. Data set 1993.

Additional file 7. Data set endogenous legislation 2005_2001_1993.

\section{Acknowledgements}

I gratefully acknowledge Karen Mumford, Thomas Cornelissen, Emma Tominey and participants at various seminars, for helpful comments as well as the financial support provided by the Mexican Council of Science and Technology (CONACYT). I especially thank an anonymous referee for precise comments and suggestions.

\section{Authors' contributions}

This is the first study to analyze the implications of unilateral legislation on divorce rates not only in Mexico but in a Latin American country, and helps to understand better the increasing number of divorces in recent years. In addition, it proves that these types of changes in the legislation are powerful tools that immediately modify outcomes within families, regardless of the social and cultural background that distinguish the Latin American region. The author read and approved the final manuscript.

\section{Funding}

Mexican National Council for Science and Technology (CONACYT)

\section{Availability of data and materials}

The datasets supporting the conclusions of this article are included within the article (and its Additional files 1, 2, 3, 4, 5, 6 and 7).

\section{Competing interests}

The author declares that there are no competing interests.

\section{Appendix}

See Figs. 1, 2 and Tables 5, 6, 7, 8, 9, 10, 11, 12, 13, 14, 15 and 16.

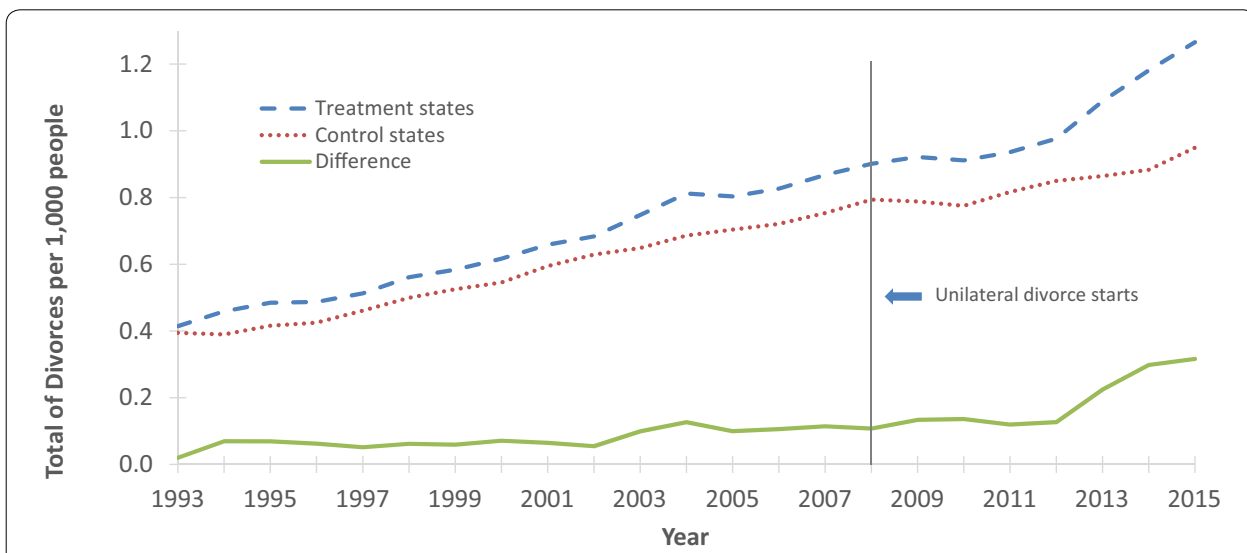

Fig. 1 Average divorce rates (Source: Author's calculations. National Institute of Statistics and Geography $($ (INEGI)) 


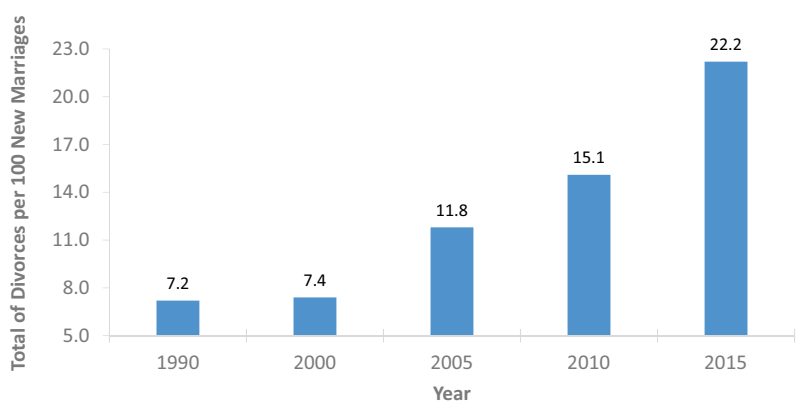

Fig. 2 Divorces per 100 new marriages in Mexico (Source: National Institute of Statistics and Geography $($ INEGI))

Table 5 Divorce rates by state-total number of divorces per 1000 people

\begin{tabular}{|c|c|c|c|c|c|c|c|c|c|c|c|}
\hline State & 2005 & 2006 & 2007 & 2008 & 2009 & 2010 & 2011 & 2012 & 2013 & 2014 & 2015 \\
\hline Aguascalientes $^{a}$ & 1.11 & 1.06 & 0.95 & 1.12 & 1.1 & 1.19 & 0.98 & 1.14 & 1.21 & 1.06 & 1.34 \\
\hline Baja California & 1.54 & 1.44 & 1.06 & 1.07 & 0.99 & 0.96 & 1.03 & 0.98 & 0.99 & 0.88 & 1.04 \\
\hline Baja California Sur & 1.04 & 0.97 & 1.03 & 1.23 & 1.09 & 0.86 & 1.05 & 1.06 & 1.15 & 0.98 & 0.96 \\
\hline Campeche & 0.98 & 1.05 & 0.97 & 1.03 & 1.07 & 1.11 & 1.16 & 1.31 & 1.35 & 1.51 & 1.33 \\
\hline Chihuahua & 1.52 & 1.22 & 1.37 & 1.39 & 1.37 & 1.46 & 1.59 & 1.72 & 1.7 & 1.6 & 1.9 \\
\hline Chiapas & 0.29 & 0.31 & 0.32 & 0.34 & 0.33 & 0.35 & 0.37 & 0.42 & 0.41 & 0.44 & 0.48 \\
\hline Coahuila $^{a}$ & 0.97 & 1.13 & 1.18 & 1.23 & 1.3 & 1.17 & 1.2 & 1.28 & 1.9 & 2.44 & 2.08 \\
\hline Colima & 1.13 & 1.22 & 1.36 & 1.36 & 1.45 & 1.39 & 1.29 & 0.95 & 1.06 & 1.25 & 1.21 \\
\hline Mexico City ${ }^{a}$ & 0.79 & 0.77 & 0.78 & 0.86 & 1.05 & 1.24 & 1.28 & 1.25 & 1.24 & 1.15 & 1.38 \\
\hline Durango & 0.73 & 0.85 & 0.88 & 0.8 & 0.81 & 0.82 & 0.85 & 0.94 & 0.91 & 1.0 & 1.09 \\
\hline Guerrero $^{a}$ & 0.37 & 0.35 & 0.41 & 0.35 & 0.35 & 0.39 & 0.38 & 0.48 & 0.66 & 0.61 & 0.56 \\
\hline Guanajuato & 0.63 & 0.67 & 0.73 & 0.79 & 0.8 & 0.8 & 0.84 & 0.84 & 1.01 & 1.08 & 1.27 \\
\hline Hidalgo ${ }^{a}$ & 0.28 & 0.3 & 0.32 & 0.35 & 0.49 & 0.48 & 0.51 & 0.69 & 0.8 & 0.89 & 0.89 \\
\hline Jalisco & 0.47 & 0.53 & 0.6 & 0.61 & 0.57 & 0.58 & 0.58 & 0.56 & 0.54 & 0.55 & 0.53 \\
\hline Mexico $^{a}$ & 0.52 & 0.53 & 0.53 & 0.53 & 0.53 & 0.53 & 0.56 & 0.8 & 1.11 & 1.13 & 1.18 \\
\hline Michoacan ${ }^{a}$ & 0.62 & 0.66 & 0.65 & 0.64 & 0.65 & 0.65 & 0.75 & 0.8 & 0.79 & 0.77 & 0.88 \\
\hline Morelos & 0.5 & 0.43 & 0.45 & 0.57 & 0.6 & 0.67 & 0.72 & 0.75 & 0.71 & 0.71 & 0.8 \\
\hline Nayarit $^{a}$ & 0.9 & 1.03 & 1.06 & 0.85 & 0.81 & 0.81 & 0.83 & 0.93 & 0.93 & 0.85 & 0.9 \\
\hline Nuevo Leon & 0.99 & 1.04 & 1.34 & 1.52 & 1.58 & 1.42 & 1.45 & 1.54 & 1.33 & 1.58 & 1.74 \\
\hline Oaxaca & 0.13 & 0.12 & 0.16 & 0.16 & 0.16 & 0.16 & 0.15 & 0.2 & 0.26 & 0.25 & 0.29 \\
\hline Puebla & 0.34 & 0.35 & 0.38 & 0.38 & 0.38 & 0.4 & 0.41 & 0.48 & 0.51 & 0.52 & 0.47 \\
\hline Queretaro & 0.67 & 0.78 & 0.79 & 0.83 & 0.73 & 0.81 & 0.85 & 0.84 & 1.08 & 1.13 & 1.32 \\
\hline Quintana Roo ${ }^{a}$ & 0.86 & 1.0 & 1.17 & 1.33 & 1.36 & 1.15 & 1.19 & 0.7 & 0.69 & 0.95 & 1.14 \\
\hline Sinaloa ${ }^{a}$ & 1.0 & 1.02 & 1.13 & 1.17 & 1.07 & 1.14 & 1.23 & 1.29 & 1.41 & 1.88 & 1.93 \\
\hline San Luis Potosi & 0.42 & 0.48 & 0.53 & 0.52 & 0.57 & 0.58 & 0.65 & 0.66 & 0.65 & 0.58 & 0.61 \\
\hline Sonora & 0.96 & 1.0 & 1.07 & 1.12 & 1.06 & 1.05 & 1.02 & 1.07 & 1.13 & 1.15 & 1.13 \\
\hline Tabasco & 0.61 & 0.69 & 0.63 & 0.77 & 0.83 & 0.7 & 0.74 & 0.78 & 0.66 & 0.72 & 0.71 \\
\hline Tamaulipas $^{\text {a }}$ & 0.58 & 0.62 & 0.68 & 0.67 & 0.6 & 0.57 & 0.62 & 0.69 & 0.58 & 0.57 & 0.95 \\
\hline Tlaxcala & 0.12 & 0.16 & 0.22 & 0.29 & 0.25 & 0.26 & 0.33 & 0.37 & 0.39 & 0.44 & 0.43 \\
\hline Veracruz & 0.45 & 0.46 & 0.49 & 0.54 & 0.53 & 0.52 & 0.57 & 0.58 & 0.61 & 0.53 & 0.55 \\
\hline Yucatán ${ }^{a}$ & 1.23 & 1.08 & 1.14 & 1.21 & 1.16 & 1.03 & 1.22 & 1.21 & 0.93 & 0.85 & 1.26 \\
\hline Zacatecas & 0.75 & 0.82 & 0.86 & 0.84 & 0.94 & 0.95 & 0.97 & 1.17 & 1.18 & 1.19 & 1.19 \\
\hline
\end{tabular}

Source: Author's calculations using National Institute of Statistics and Geography (INEGI) information

Italicized cells indicate the year when the state adopted unilateral divorce

a States with unilateral divorce legislation. In 2016, Baja California Sur, Colima, Morelos, Nuevo Leon, Puebla and Tlaxcala, also modified their legislation toward no-fault divorce, but 2016 divorce data are not yet available 
Table 6 Correlation coefficients

\begin{tabular}{llc}
\hline Initial divorce rate & $\begin{array}{l}\text { Divorce rates vs. adoption of unilateral } \\
\text { legislation }\end{array}$ & $\begin{array}{l}\text { Divorce rates vs. } \\
\text { year adopting unilateral } \\
\text { legislation }\end{array}$ \\
\hline 2005 & $0.1286(0.4830)$ & $0.4318(0.2127)$ \\
2001 & $0.1062(0.5630)$ & $0.3385(0.3388)$ \\
1993 & $0.0431(0.8147)$ & $-0.0639(0.8608)$ \\
\hline
\end{tabular}

Source: Author's calculations using National Institute of Statistics and Geography (INEGI) data and information from the standing legislation in each state

Significance levels in parentheses

Table 7 Static effects on divorce rates-excluding year-fixed effects

\begin{tabular}{|c|c|c|c|c|}
\hline & (1) & (2) & (3) & (4) \\
\hline Unilateral & $\begin{array}{l}0.394^{* * *} \\
(0.0532)\end{array}$ & $\begin{array}{l}0.435^{* * *} \\
(0.0257)\end{array}$ & $\begin{array}{l}0.303^{* * *} \\
(0.0307)\end{array}$ & $\begin{array}{l}0.215^{* * *} \\
(0.0323)\end{array}$ \\
\hline Adjusted $R^{2}$ & 0.133 & 0.871 & 0.941 & 0.955 \\
\hline Year effects & No & No & No & No \\
\hline \multicolumn{5}{|l|}{ Prob $>F$} \\
\hline State effects & No & Yes, $F=65.41$ & Yes, $F=38.10$ & Yes, $F=29.19$ \\
\hline Prob $>F$ & & 0.000 & 0.000 & 0.000 \\
\hline State trend, linear & No & No & $Y e s, F=13.28$ & $Y e s, F=2.69$ \\
\hline Prob $>F$ & & & 0.000 & 0.000 \\
\hline State trend, quadratic & No & No & No & $Y e s, F=3.82$ \\
\hline Prob $>F$ & & & & 0.000 \\
\hline Total of observations & 352 & 352 & 352 & 352 \\
\hline
\end{tabular}

Source: National Institute of Statistics and Geography (INEGI) and standing legislation in each state. Divorce rates are measured as total of divorces per thousand people. Standard errors are in parentheses. All regressions include a constant term and are estimated using state and year population-weighted least squares

***Statistically significant at the $99 \%$ confidence level

Table 8 Static effects on divorce rates-1993 to 2015

\begin{tabular}{|c|c|c|c|c|}
\hline & (1) & (2) & (3) & (4) \\
\hline Unilateral & $\begin{array}{l}0.526^{* * *} \\
(0.0466)\end{array}$ & $\begin{array}{l}0.264^{* * *} \\
(0.0241)\end{array}$ & $\begin{array}{l}0.323^{* * *} \\
(0.0223)\end{array}$ & $\begin{array}{l}0.319^{* * *} \\
(0.0260)\end{array}$ \\
\hline Adjusted $R^{2}$ & 0.146 & 0.865 & 0.937 & 0.952 \\
\hline Year effects & No & Yes, $F=38.49$ & Yes, $F=3.36$ & Yes, $F=4.69$ \\
\hline Prob $>F$ & & 0.000 & 0.000 & 0.000 \\
\hline State effects & No & Yes, $F=100.60$ & $Y e s, F=36.93$ & $Y e s, F=18.39$ \\
\hline Prob $>F$ & & 0.000 & 0.000 & 0.000 \\
\hline State trend, linear & No & No & Yes, $F=26.23$ & Yes, $F=6.26$ \\
\hline Prob $>F$ & & & 0.000 & 0.000 \\
\hline State trend, quadratic & No & No & No & Yes, $F=7.14$ \\
\hline Prob $>F$ & & & & 0.000 \\
\hline Total of observations & 736 & 736 & 736 & 736 \\
\hline
\end{tabular}

Source: National Institute of Statistics and Geography (INEGI), National Population Council (CONAPO) for states' population from 1993 to 2004, and standing legislation in each state. Divorce rates are measured as total of divorces per thousand people. Standard errors are in parentheses. All regressions include a constant term and are estimated using state and year population-weighted least squares

***Statistically significant at the $99 \%$ confidence level 
Table 9 Static effects on divorce rates-2005 to 2015-control variables

\begin{tabular}{|c|c|c|c|c|}
\hline & (1) & (2) & (3) & (4) \\
\hline Unilateral & $\begin{array}{l}0.133^{* * *} \\
(0.0480)\end{array}$ & $\begin{array}{l}0.289^{* * *} \\
(0.0275)\end{array}$ & $\begin{array}{l}0.302^{* * *} \\
(0.0317)\end{array}$ & $\begin{array}{l}0.225^{* * *} \\
(0.0352)\end{array}$ \\
\hline Education & $\begin{array}{l}0.248^{* * *} \\
(0.0346)\end{array}$ & $\begin{array}{l}-0.182 \\
(0.129)\end{array}$ & $\begin{array}{l}-0.187 \\
(0.427)\end{array}$ & $\begin{array}{l}-0.103 \\
(0.494)\end{array}$ \\
\hline Female labor force & $\begin{array}{l}-0.010^{* *} \\
(0.0043)\end{array}$ & $\begin{array}{l}0.006 \\
(0.0049)\end{array}$ & $\begin{array}{l}0.009^{*} \\
(0.0051)\end{array}$ & $\begin{array}{l}-0.003 \\
(0.0060)\end{array}$ \\
\hline Fertility & $\begin{array}{l}-0.003 \\
(0.0018)\end{array}$ & $\begin{array}{l}0.001 \\
(0.0015)\end{array}$ & $\begin{array}{l}0.001 \\
(0.0016)\end{array}$ & $\begin{array}{l}0.002 \\
(0.0016)\end{array}$ \\
\hline GDP & $\begin{array}{l}0.002 \\
(0.0047)\end{array}$ & $\begin{array}{l}0.0001 \\
(0.0035)\end{array}$ & $\begin{array}{l}-0.001 \\
(0.0028)\end{array}$ & $\begin{array}{l}-0.0009 \\
(0.0027)\end{array}$ \\
\hline Unemployment & $\begin{array}{l}-0.038^{* *} \\
(0.0156)\end{array}$ & $\begin{array}{l}-0.053^{* * *} \\
(0.0128)\end{array}$ & $\begin{array}{l}-0.027^{* *} \\
(0.0110)\end{array}$ & $\begin{array}{l}-0.009 \\
(0.0136)\end{array}$ \\
\hline Adjusted $R^{2}$ & 0.425 & 0.903 & 0.945 & 0.955 \\
\hline Year effects & No & Yes, $F=1.94$ & Yes, $F=0.85$ & Yes, $F=0.49$ \\
\hline Prob $>F$ & & 0.040 & 0.577 & 0.892 \\
\hline State effects & No & Yes, $F=55.02$ & Yes, $F=24.46$ & Yes, $F=14.89$ \\
\hline Prob $>F$ & & 0.000 & 0.000 & 0.000 \\
\hline State trend, linear & No & No & Yes, $F=8.39$ & Yes, $F=2.42$ \\
\hline Prob $>F$ & & & 0.000 & 0.000 \\
\hline State trend, quadratic & No & No & No & $Y e s, F=2.91$ \\
\hline Prob $>F$ & & & & 0.000 \\
\hline Total of observations & 352 & 352 & 352 & 352 \\
\hline
\end{tabular}

Source: National Institute of Statistics and Geography (INEGI) and standing legislation in each state. Divorce rates are measured as total of divorces per thousand people. Standard errors are in parentheses. All regressions include a constant term and are estimated using state and year population-weighted least squares

*Statistically significant at the $90 \%$ confidence level

**Statistically significant at the $95 \%$ confidence level

***Statistically significant at the $99 \%$ confidence level 
Table 10 Dynamic effects on divorce rates-2005 to 2015-control variables

\begin{tabular}{|c|c|c|c|c|}
\hline & (1) & (2) & (3) & (4) \\
\hline \multicolumn{5}{|l|}{ Unilateral } \\
\hline First 2 years & $\begin{array}{l}0.141^{* *} \\
(0.0643)\end{array}$ & $\begin{array}{l}0.261^{* * *} \\
(0.0317)\end{array}$ & $\begin{array}{l}0.279^{* * *} \\
(0.0329)\end{array}$ & $\begin{array}{l}0.211^{* * *} \\
(0.0373)\end{array}$ \\
\hline Years 3 and 4 & $\begin{array}{l}0.167^{* *} \\
(0.0682)\end{array}$ & $\begin{array}{l}0.335^{* * *} \\
(0.0354)\end{array}$ & $\begin{array}{l}0.368^{* * *} \\
(0.0449)\end{array}$ & $\begin{array}{l}0.213^{* * *} \\
(0.0621)\end{array}$ \\
\hline 5 years or more & $\begin{array}{l}-0.017 \\
(0.111)\end{array}$ & $\begin{array}{l}0.222^{* * *} \\
(0.0575)\end{array}$ & $\begin{array}{l}0.270^{* * *} \\
(0.0832)\end{array}$ & $\begin{array}{l}0.037 \\
(0.110)\end{array}$ \\
\hline Education & $\begin{array}{l}0.256^{* * *} \\
(0.0350)\end{array}$ & $\begin{array}{l}-0.190 \\
(0.131)\end{array}$ & $\begin{array}{l}-0.250 \\
(0.421)\end{array}$ & $\begin{array}{l}-0.057 \\
(0.491)\end{array}$ \\
\hline Female labor force & $\begin{array}{l}-0.009^{* *} \\
(0.0043)\end{array}$ & $\begin{array}{l}0.006 \\
(0.0049)\end{array}$ & $\begin{array}{l}0.007 \\
(0.0050)\end{array}$ & $\begin{array}{l}-0.004 \\
(0.0059)\end{array}$ \\
\hline Fertility & $\begin{array}{l}-0.002 \\
(0.0018)\end{array}$ & $\begin{array}{l}0.002 \\
(0.0015)\end{array}$ & $\begin{array}{l}0.001 \\
(0.0015)\end{array}$ & $\begin{array}{l}0.002 \\
(0.0016)\end{array}$ \\
\hline GDP & $\begin{array}{l}0.001 \\
(0.0047)\end{array}$ & $\begin{array}{l}-0.00001 \\
(0.0034)\end{array}$ & $\begin{array}{l}-0.002 \\
(0.0028)\end{array}$ & $\begin{array}{l}-0.0009 \\
(0.0027)\end{array}$ \\
\hline Unemployment & $\begin{array}{l}-0.040^{* * *} \\
(0.0158)\end{array}$ & $\begin{array}{l}-0.053^{* * *} \\
(0.0127)\end{array}$ & $\begin{array}{l}-0.028^{* * *} \\
(0.0109)\end{array}$ & $\begin{array}{l}-0.007 \\
(0.0135)\end{array}$ \\
\hline Adjusted $R^{2}$ & 0.426 & 0.905 & 0.947 & 0.955 \\
\hline Year effects & No & Yes, $F=1.86$ & Yes, $F=0.63$ & Yes, $F=0.59$ \\
\hline Prob $>F$ & & 0.050 & 0.781 & 0.819 \\
\hline State effects & No & Yes, $F=55.48$ & Yes, $F=24.20$ & Yes, $F=14.96$ \\
\hline Prob $>F$ & & 0.000 & 0.000 & 0.000 \\
\hline State trend, linear & No & No & Yes, $F=8.66$ & Yes, $F=2.32$ \\
\hline Prob $>F$ & & & 0.000 & 0.000 \\
\hline State trend, quadratic & No & No & No & Yes, $F=2.72$ \\
\hline Prob $>F$ & & & & 0.000 \\
\hline Equality of coefficients & $F=1.18$ & $F=3.09$ & $F=5.45$ & $F=2.90$ \\
\hline Prob $>F$ & 0.307 & 0.046 & 0.004 & 0.056 \\
\hline Total of observations & 352 & 352 & 352 & 352 \\
\hline
\end{tabular}

Source: National Institute of Statistics and Geography (INEGI) and standing legislation in each state. Divorce rates are measured as total of divorces per thousand people. Standard errors are in parentheses. All regressions include a constant term and are estimated using state and year population-weighted least squares

**Statistically significant at the $95 \%$ confidence level

***Statistically significant at the $99 \%$ confidence level

Table 11 Static effects on divorce rates-2005 to 2015-OLS

\begin{tabular}{|c|c|c|c|c|}
\hline & (1) & (2) & (3) & (4) \\
\hline Unilateral & $\begin{array}{l}0.308^{* * *} \\
(0.0666)\end{array}$ & $\begin{array}{l}0.213^{* * *} \\
(0.0351)\end{array}$ & $\begin{array}{l}0.194^{* * *} \\
(0.0393)\end{array}$ & $\begin{array}{l}0.154^{* * *} \\
(0.0435)\end{array}$ \\
\hline Adjusted $R^{2}$ & 0.055 & 0.862 & 0.927 & 0.940 \\
\hline Year effects & No & Yes, $F=6.56$ & Yes, $F=1.47$ & Yes, $F=1.39$ \\
\hline Prob $>F$ & & 0.000 & 0.149 & 0.182 \\
\hline State effects & No & Yes, $F=65.08$ & Yes, $F=37.15$ & $Y e s, F=25.34$ \\
\hline Prob $>F$ & & 0.000 & 0.000 & 0.000 \\
\hline State trend, linear & No & No & Yes, $F=9.95$ & $Y e s, F=2.15$ \\
\hline Prob $>F$ & & & 0.000 & 0.001 \\
\hline State trend, quadratic & No & No & No & Yes, $F=2.93$ \\
\hline Prob $>F$ & & & & 0.000 \\
\hline Total of observations & 352 & 352 & 352 & 352 \\
\hline
\end{tabular}

Source: National Institute of Statistics and Geography (INEGI) and standing legislation in each state. Divorce rates are measured as total of divorces per thousand people. Standard errors are in parentheses. All regressions include a constant term and are estimated using ordinary least squares

***Statistically significant at the $99 \%$ confidence level 
Table 12 Dynamic effects on divorce rates-2005 to 2015-OLS

\begin{tabular}{lllll}
\hline & $\mathbf{( 1 )}$ & $\mathbf{( 2 )}$ & $\mathbf{( 3 )}$ & $\mathbf{( 4 )}$ \\
\hline Unilateral & & & & \\
First 2 years & $0.292^{* * *}$ & $0.184^{* * *}$ & $0.181^{* * *}$ & $0.145^{* * *}$ \\
& $(0.0909)$ & $(0.0407)$ & $(0.0403)$ & $(0.0469)$ \\
Years 3 and 4 & $0.321^{* * *}$ & $0.255^{* * *}$ & $0.244^{* * *}$ & $0.157^{*}$ \\
& $(0.106)$ & $(0.0490)$ & $(0.0581)$ & $(0.0842)$ \\
5 years or more & $0.337^{*}$ & $0.267^{* * *}$ & 0.142 & -0.00525 \\
& $(0.189)$ & $(0.0871)$ & $(0.112)$ & $(0.157)$ \\
Adjusted $R^{2}$ & 0.050 & 0.862 & 0.928 & 0.940 \\
Year effects & No & Yes, F=5.99 & Yes, F=1.24 & Yes, $F=1.40$ \\
Prob $>F$ & & 0.000 & 0.265 & 0.179 \\
State effects & No & Yes, F=65.15 & Yes, F=37.27 & Yes, $F=25.25$ \\
Prob $>F$ & 0.000 & 0.000 & 0.000 \\
State trend, linear & No & No & Yes, F=9.98 & Yes, $F=2.09$ \\
Prob $>F$ & & & 0.000 & 0.001 \\
State trend, quadratic & No & No & No & Yes, $F=2.89$ \\
Prob $>F$ & & & & 0.000 \\
Equality of coefficients & $F=0.04$ & $F=1.03$ & $F=1.68$ & $F=1.27$ \\
Prob $>F$ & 0.964 & 0.358 & 0.187 & 0.281 \\
Total of observations & 352 & 352 & 352 & 352 \\
\hline
\end{tabular}

Source: National Institute of Statistics and Geography (INEGI) and standing legislation in each state. Divorce rates are measured as total of divorces per thousand people. Standard errors are in parentheses. All regressions include a constant term and are estimated using ordinary least squares

*Statistically significant at the $90 \%$ confidence level

***Statistically significant at the $99 \%$ confidence level

Table 13 Static effects on divorce rates-2005 to 2015-WLS—divorce rate in log

\begin{tabular}{|c|c|c|c|c|}
\hline & (1) & (2) & (3) & (4) \\
\hline Unilateral & $\begin{array}{l}0.499 * * * \\
(0.0723)\end{array}$ & $\begin{array}{l}0.332 * * * \\
(0.0297)\end{array}$ & $\begin{array}{l}0.325^{* * *} \\
(0.0335)\end{array}$ & $\begin{array}{l}0.262^{* * *} \\
(0.0353)\end{array}$ \\
\hline Adjusted $R^{2}$ & 0.117 & 0.931 & 0.966 & 0.974 \\
\hline Year effects & No & Yes, $F=14.62$ & Yes, $F=1.73$ & Yes, $F=1.82$ \\
\hline Prob $>F$ & & 0.000 & 0.074 & 0.058 \\
\hline State effects & No & Yes, $F=130.2$ & Yes, $F=99.79$ & Yes, $F=69.51$ \\
\hline Prob $>F$ & & 0.000 & 0.000 & 0.000 \\
\hline State trend, linear & No & No & Yes, $F=11.00$ & Yes, $F=3.41$ \\
\hline Prob $>F$ & & & 0.000 & 0.000 \\
\hline State trend, quadratic & No & No & No & $Y e s, F=3.91$ \\
\hline Prob $>F$ & & & & 0.000 \\
\hline Total of observations & 352 & 352 & 352 & 352 \\
\hline
\end{tabular}

Source: National Institute of Statistics and Geography (INEGI) and standing legislation in each state. Divorce rates are measured as total of divorces per thousand people. Standard errors are in parentheses. All regressions include a constant term and are estimated using ordinary least squares

***Statistically significant at the $99 \%$ confidence level 
Table 14 Dynamic effects on divorce rates-2005 to 2015-WLS—divorce rate in log

\begin{tabular}{lllll}
\hline & $\mathbf{( 1 )}$ & $\mathbf{( 2 )}$ & $\mathbf{( 3 )}$ & $\mathbf{( 4 )}$ \\
\hline Unilateral & & & & \\
First 2 years & $0.427^{* * *}$ & $0.287^{* * *}$ & $0.301^{* * *}$ & $0.247^{* * *}$ \\
& $(0.104)$ & $(0.0351)$ & $(0.0348)$ & $(0.0376)$ \\
Years 3 and 4 & $0.535^{* * *}$ & $0.401^{* * *}$ & $0.400^{* * *}$ & $0.245^{* * *}$ \\
& $(0.109)$ & $(0.0383)$ & $(0.0475)$ & $(0.0631)$ \\
5 years or more & $0.614^{* * *}$ & $0.277^{* * *}$ & $0.294^{* * *}$ & 0.0708 \\
& $(0.172)$ & $(0.0609)$ & $(0.0878)$ & $(0.112)$ \\
Adjusted $R^{2}$ & 0.115 & 0.933 & 0.967 & 0.974 \\
Year effects & No & Yes, F=13.94 & Yes, F=1.64 & Yes, F=2.07 \\
Prob $>F$ & & 0.000 & 0.093 & 0.027 \\
State effects & No & Yes, F=133.1 & Yes, F=102.7 & Yes, $F=70.44$ \\
Prob $>F$ & 0.000 & 0.000 & 0.000 \\
State trend, linear & No & No & Yes, F=11.20 & Yes, $F=3.28$ \\
Prob $>F$ & & & 0.000 & 0.000 \\
State trend, quadratic & No & No & No & Yes, $F=3.64$ \\
Prob $>F$ & & & & 0.000 \\
Equality of coefficients & $F=0.54$ & $F=4.30$ & $F=5.90$ & $F=2.74$ \\
Prob $>F$ & 0.581 & 0.014 & 0.003 & 0.066 \\
Total of observations & 352 & 352 & 352 & 352 \\
\hline
\end{tabular}

Source: National Institute of Statistics and Geography (INEGI) and standing legislation in each state. Divorce rates are measured as total of divorces per thousand people. Standard errors are in parentheses. All regressions include a constant term and are estimated using ordinary least squares

*Statistically significant at the $90 \%$ confidence level

***Statistically significant at the $99 \%$ confidence level

Table 15 Static effects on divorce rates-2005 to 2015-OLS-divorce rate in log

\begin{tabular}{|c|c|c|c|c|}
\hline & (1) & (2) & (3) & (4) \\
\hline Unilateral & $\begin{array}{l}0.359^{* * *} \\
(0.0927)\end{array}$ & $\begin{array}{l}0.190^{* * *} \\
(0.0388)\end{array}$ & $\begin{array}{l}0.182^{* * *} \\
(0.0397)\end{array}$ & $\begin{array}{l}0.148^{* * *} \\
(0.0442)\end{array}$ \\
\hline Adjusted $R^{2}$ & 0.038 & 0.911 & 0.961 & 0.968 \\
\hline Year effects & No & Yes, $F=11.30$ & Yes, $F=1.34$ & $Y e s, F=1.64$ \\
\hline Prob $>F$ & & 0.000 & 0.208 & 0.094 \\
\hline State effects & No & Yes, $F=108.4$ & Yes, $F=106.8$ & Yes, $F=71.79$ \\
\hline Prob $>F$ & & 0.000 & 0.000 & 0.000 \\
\hline State trend, linear & No & No & Yes, $F=13.71$ & Yes, $F=3.41$ \\
\hline Prob $>F$ & & & 0.000 & 0.000 \\
\hline State trend, quadratic & No & No & No & $Y e s, F=2.87$ \\
\hline Prob $>F$ & & & & 0.000 \\
\hline Total of observations & 352 & 352 & 352 & 352 \\
\hline
\end{tabular}

Source: National Institute of Statistics and Geography (INEGI) and standing legislation in each state. Divorce rates are measured as total of divorces per thousand people. Standard errors are in parentheses. All regressions include a constant term and are estimated using ordinary least squares

***Statistically significant at the $99 \%$ confidence level 
Table 16 Dynamic effects on divorce rates-2005 to 2015-OLS—divorce rate in log

\begin{tabular}{|c|c|c|c|c|}
\hline & (1) & (2) & (3) & (4) \\
\hline \multicolumn{5}{|l|}{ Unilateral } \\
\hline First 2 years & $\begin{array}{l}0.325^{* *} \\
(0.126)\end{array}$ & $\begin{array}{l}0.141^{* * *} \\
(0.0449)\end{array}$ & $\begin{array}{l}0.164^{* * *} \\
(0.0406)\end{array}$ & $\begin{array}{l}0.139 * * * \\
(0.0476)\end{array}$ \\
\hline Years 3 and 4 & $\begin{array}{l}0.378^{* *} \\
(0.148)\end{array}$ & $\begin{array}{l}0.260^{* * *} \\
(0.0541)\end{array}$ & $\begin{array}{l}0.236^{* * *} \\
(0.0586)\end{array}$ & $\begin{array}{l}0.160^{*} \\
(0.0853)\end{array}$ \\
\hline 5 years or more & $\begin{array}{l}0.448^{*} \\
(0.263)\end{array}$ & $\begin{array}{l}0.286^{* * *} \\
(0.0960)\end{array}$ & $\begin{array}{l}0.0972 \\
(0.113)\end{array}$ & $\begin{array}{l}-0.0232 \\
(0.159)\end{array}$ \\
\hline Adjusted $R^{2}$ & 0.033 & 0.912 & 0.961 & 0.968 \\
\hline Year effects & No & Yes, $F=10.63$ & $Y e s, F=1.31$ & $Y e s, F=1.68$ \\
\hline Prob $>F$ & & 0.000 & 0.222 & 0.085 \\
\hline State effects & No & Yes, $F=109.5$ & Yes, $F=107.9$ & Yes, $F=71.9$ \\
\hline Prob $>F$ & & 0.000 & 0.000 & 0.000 \\
\hline State trend, linear & No & No & Yes, $F=13.67$ & Yes, $F=3.28$ \\
\hline Prob $>F$ & & & 0.000 & 0.000 \\
\hline State trend, quadratic & No & No & No & $Y e s, F=2.80$ \\
\hline Prob $>F$ & & & & 0.000 \\
\hline Equality of coefficients & $F=0.10$ & $F=2.43$ & $F=2.55$ & $F=1.70$ \\
\hline Prob $>F$ & 0.900 & 0.090 & 0.080 & 0.185 \\
\hline Total of observations & 352 & 352 & 352 & 352 \\
\hline
\end{tabular}

Source: National Institute of Statistics and Geography (INEGI) and standing legislation in each state. Divorce rates are measured as total of divorces per thousand people. Standard errors are in parentheses. All regressions include a constant term and are estimated using ordinary least squares

*Statistically significant at the $90 \%$ confidence level

**Statistically significant at the $95 \%$ confidence level

***Statistically significant at the $99 \%$ confidence level

Received: 23 April 2018 Accepted: 4 October 2019

Published online: 17 October 2019

\section{References}

Allen DW (1992) Marriage and divorce: comment. Am Econ Rev 82:679-685

Allen DW (1998) No-fault divorce in Canada: its cause and effect. J Econ Behav Organ 37:129-149

Bai J (2009) Panel data models with interactive fixed effects. Econometrica 77:1229-1279

Becker GS (1991) A treatise on the family. Harvard University Press Enlarged version, Cambridge

Becker GS, Landes EM, Michael RT (1977) An economic analysis of marital instability. J Polit Econ 85:1141-1187

Caceres-Delpiano J, Giolito E (2012) The impact of unilateral divorce on crime. J Labor Econ 30:215-248

Chiappori PA, Mt Iyigun, Weiss Y (2015) The Becker-Coase theorem reconsidered. J Demogr Econ 81:157-177

Clark SJ (1999) Law, property, and marital dissolution. Econ J 109:C41-C54

Coase RH (1960) The problem of social cost. J Law Econ 56:837-877

Conley TG, Taber CR (2011) Inference with difference in differences with a small number of policy changes. Rev Econ Stat 93:113-125

Donald SG, Lang K (2007) Inference with difference in differences and other panel data. Rev Econ Stat 89:221-233

Droes M, Lamoen R (2010) Did unilateral divorce laws raise divorce rates? A reconciliation and new results: comment. Utrecht School of Economics, Discussion Paper Series 10-11

Ferman B, Pinto C (2018) Inference in differences in differences with few treated groups and heteroscedasticity. Rev Econ Stat. https://doi.org/10.1162/rest_a_00759 (forthcoming)

Friedberg $L$ (1998) Did unilateral divorce raise divorce rates? Evidence from panel data. Am Econ Rev 88:608-627

Gonzalez L, Viitanen TK (2009) The effect of divorce laws on divorce rates in Europe. Eur Econ Rev 53:127-138

Gruber J (2004) Is making divorce easier bad for children? The long-run implications of unilateral divorce. J Labor Econ 22:799-833

Hsiao C (2014) Analysis of panel data, 3rd edn. Cambridge University Press, Cambridge

Kim D, Oka T (2014) Divorce law reforms and divorce rates in the USA: an interactive fixed-effects approach. J Appl Econom 29:231-245

Lee J, Solon G (2011) The fragility of estimated effects of unilateral divorce laws on divorce rates. BE J Econ Anal Poli 11 Article 49 
Mechoulan S (2005) Economic theory's stance on no-fault divorce. Rev Econ Househ 3:337-359

Moon HR, Weidner M (2015) Linear regression for panel with unknown number of factors as interactive fixed effects. Econometrica 83:1543-1579

Organisation for Economic Co-operation and Development (OECD) (2017) Building an inclusive Mexico: policies and good governance for gender equality. OECD Publishing, Paris

Peters HE (1986) Marriage and divorce: informational constraints and private contracting. Am Econ Rev 76:437-454 Stevenson B (2007) The impact of divorce laws on marriage-specific capital. J Labor Econ 25:75-94

Stevenson B, Wolfers J (2006) Bargaining in the shadow of the law: divorce laws and family distress. Q J Econ 121:267-288

Wolfers J (2006) Did unilateral divorce laws raise divorce rates? A reconciliation and new results. Am Econ Rev 96:1802-1820

\section{Publisher's Note}

Springer Nature remains neutral with regard to jurisdictional claims in published maps and institutional affiliations.

Submit your manuscript to a SpringerOpen ${ }^{0}$ journal and benefit from:

- Convenient online submission

- Rigorous peer review

- Open access: articles freely available online

- High visibility within the field

- Retaining the copyright to your article

Submit your next manuscript at $\gg$ springeropen.com 